\title{
玉野製錬所自電炉におけるエネルギ一回収と 代替燃料技術の確立
}

\section{柴 田 隆 顯}

[UDC 669.33:662.994:620.97]

\author{
Energy Recovery and Substitute Fuel Technology in the Flash Smelting \\ Furnace with Electrodes (FSFE) at Tamano Smelter \\ by Takaaki SHIBATA ${ }^{1}$ \\ 1. Director, General Manager, Tamano Smelter, HIBI KYODO SMELTING CO., LTD., \\ 6-1-1, Hibi, Tamano, Okayama 706
}

The Tamano Smelter is a large scale coastal facility which started operations in 1972 employing the FSFE process. The FSFE is a Outokumpu type flash smelting furnace to which electrodes have been added to the settler and the up-take is equipped with a water-cooled jacket. With respect to hearth maintenance and the elimination of boiler trouble, this type is superior to the conventional type flash smelting furnace.

In the initial start-up, the Tamano Smelter was producing 101,000 tons of anodes a year, and through the introduction of a two step oxygen enrichment, process production has been increased to the present 196,000 tons per year. During this period the two so called oil shocks of 1973 and 1979 resulted in a dramatic rise in energy cost. To cope with this an energy saving program was instituted to reduce production costs.

This paper focuses on the energy savings associated with the flash smelting furnace. First, the water-cooled up-take was replaced by a boiler from which waste heat could be recovered, and secondly, the fuel was changed from heavy oil to coke. In addition, the fuel change resulted in an auxiliary benefit. Through the development of a FSFE operational technology called carbon monoxide concentration control, the special qualities of coke could be utilized and the charging of the electrodes in the settler was eliminated.

KEY WORDS: Tamano Smelter, FSFE, Substitute Fuel Technology, Energy Recovery

\section{1. 緒言}

玉野製錬所は, 昭和 47 年に操業を開始した自電炉法および高電 流密度電解法を特徵とした大型臨海共同製錬所である。昭和 59 年 に第 2 次増産工事が完成し電気銅 $137,000 \mathrm{t} /$ 年, 粗銅 $196,000 \mathrm{t} /$ 年 の体制が確立した。

当所では，操業当初より熔鍊炉としてOutokumpuタイプ自溶炉 のセットラに電気炉を備え, 水冷ジャケット式アップテークを用 いた「自電炉」を採用した。本方式は一般の自熔炉方式と比べュ スト, 炬床維持, ボイラでのダストトラブル防止の面で優れてお り, 当所では操業開始以来, これらの特徵を活かしながら順調な 操業を行ってきた。

しかしながら, 昭和 48 年の第 1 次オイルショック, 昭和 54 年の 第 2 次オイルショックにより, 重油, 電力価格が高騰し, 受託製 錬所としての競争力を維持するため, 省エネルギーによるコスト 削減が重要な課題となった。

自電炬における省エネルギー技術を開発する中で，水冷ジャケ ット式アップテークのボイラ化による廃熱の回収とともに重油か

* 平成 2 年 $(1990$ 年) 3 月 29 日, 本会総会にて第 64 回渡辺賞を受 賞された。

1. 正会員 日比共同製鍊 (株) 専務取締役, 玉野製錬所所長

キーワード: 玉野製錬所, 自電炉, 燃料転換技術, エネルギー回収
ら石炭，石炭からコークスへの燃料転換を進め，これら炭材の特 徵を活かした自電炉操業技術を開発し, 最終的には当初設置した 電気炉を使用せずに操業できる技術を確立した。

以下，これら技術開発の経緯ならびに効果について説明する。

\section{2. 工 程 概 要}

玉野製鍊所の工程フローシートを図 1 に示す。

各種銅精鉱はベッディング方式で調合し, 気流乾燥を通った後 に自電炉へ装入される。自電炉では精鉱（銅品位 約 $29 \%$ ) の溶 解と, 鉄, 硫黄の酸化が行われ, 銅品位約 $60 \%$ のマットに濃縮さ れる。マットは転炉，精製炉を経て銅品位約 $99 \%$ まで濃縮された 後にアノードとして鋳込まれる。

自電炉, 転炉から排出される高濃度の $\mathrm{SO}_{2}$ ガスは硫酸工場で硫 酸として回収され，その他の希薄な $\mathrm{SO}_{2}$ ガスは排脱工場で石膏と して回収される。

熔錬工場で生産されたアノードは電錬工場で精製され, 99.99\% の電気銅となる。また，金銀スライム等が副産物として産出され る。

\section{3. 自電炉の採用とその特徵}

\section{$3 \cdot 1$ 自電炉の採用経緯}

玉野製錬所の基本設計に際して, 乾式製錬の中心である熔錬炉 


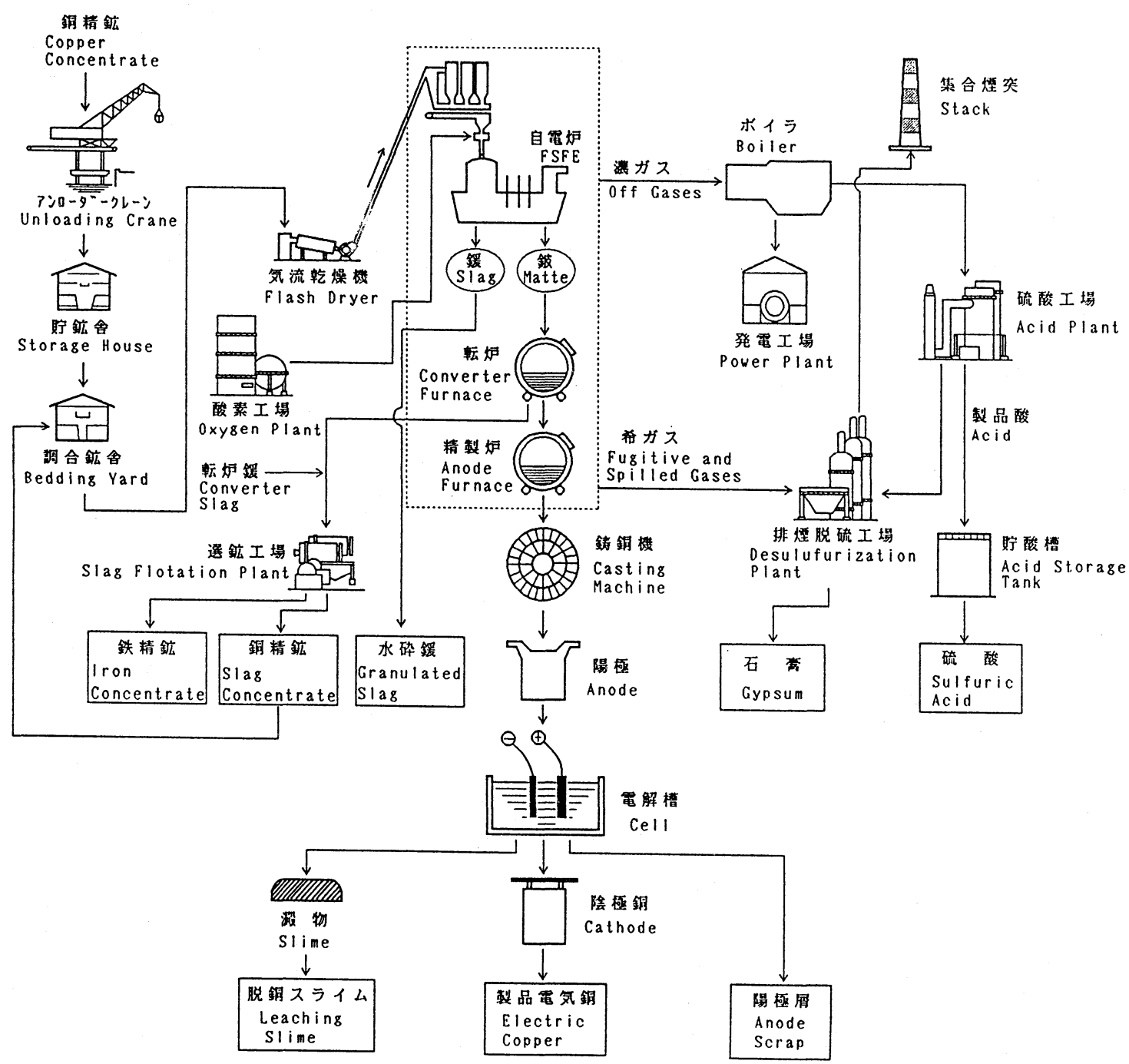

図1玉野製錬所フローシート

の選択については, 硫黄回収ならびに公害防止の有利性, 燃料の経 済性, 操業コントロールの容易さ, 労働生産性の高いこと等を考 慮し自熔炉を採用することとした ${ }^{1)}$ 。

しかし当時自熔炉方式にも，

(1) ダストを伴った高温排ガスのため, 廃熱ボイラにおいて ダストトラブルが起こり, 操業度が低下する。

(2) 産出スラグは銅品位が高く鍊鍰炉等による後処理を要する。 などの問題点が残されていた。

一方, 当時古河鉱業足尾製錬所では, テスト用として自熔灯セ ットラ部に電極を設置した方式の小型試験炉 (自電炬) が稼動し ていた。

この試験炬の設備および操業データよりこの方式は,

(1) 水冷ジャケット方式によるアップテークにより, 廃熱ボイ ラのダストトラブルを大幅に減少させる可能性がある。

(2) 電極をセットラ内に設置することにより，水冷ジャケット 式アップテークより落下するダストのセットラ内での溶解ととも に，スラグの錬鍰が同時に行え，そのため設備がコンパクトにな るとともに, 自熔炬 (および鍊鍰炬) でのエネルギーコストが削減 できる。

等の大きな利点があると判断された。

小型試験炬から，一挙に大型のコマーシャル炬へ払大するに当 たっては，大型設備の設計，建設，および炬の実操業面で種々の
リスクが伴なうことも懸念されたが，本方式の利点が大きいこと により新しい玉野製錬所の熔錬方式として，本自電炉方式の採用 に踏み切った。

図 2 に玉野自電炉概略図を示す。

$3 \cdot 2$ 水冷ジャケット式アップテーク

（1）採用理由通常の自熔炉排ガスは，レンガ積みのアップ テークを通して付属の廃熱ボイラに導入されるが，ダストによる アップテークの閉塞を避けるためにアップテーク内部を高温に保 持し付着ダストを溶融させる。このため廃熱ボイラに入る排ガス は溶融ダストを含むことになり，これがボイラ管壁に付着成長し て伝熱を悪化させ, ボイラ出口排ガス温度を上昇させたり通気抵 抗を增大させたりする。また，場合によってはダストの大塊がホ ッパ部に落下し設備を損傷するケースもある。

このようなボイラトラブルを解決するには,

(1) ボイラ入ロガス温度を低下させること。

(2) ボイラ内のガスフローを適正にすること。

(3) ボイラ内管壁構造をダストが落ち易いものにすること。 などの対策が必要となる。

その中でも(1)が最重要課題であり，その対策として，従来法と は根本的に異なる水冷ジャケット式のアップテークを採用するこ ととした。炬の排ガス温度を，アップテーク部で約 $200{ }^{\circ} \mathrm{C}$ 下げて $1,100^{\circ} \mathrm{C}$ 程度にしてボイラへ導入することによって, ボイラ輻射 


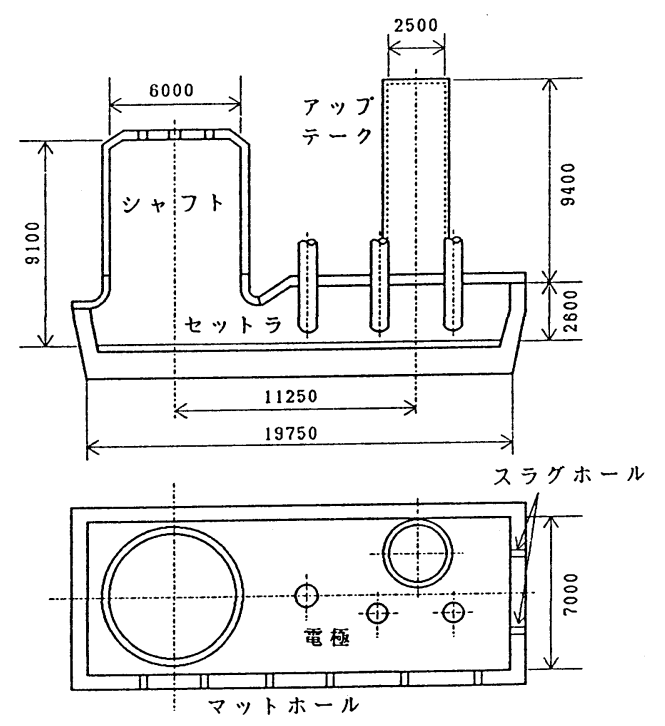

図2自電炉概略図

部でのダストトラブルを解消することを狙ったものである。

（2）構造水冷ジャケット式アップテーク表面には炉排ガス 中の溶融ダストが集中的に付着することが想定されるため，その 基本構造は垂直円筒型とし, 表面が平滑で, ダストが剥離し易い 構造のものとした。

実際製作面から，一体にするか分割にするか，分割の場合はど のように分割するかを検討し，製作面と現場組立面との関係を加 味し，高さ方向で 7 分割，全体では 22 ブロックに分割する構造と した。

（3）材質材質の決定に当たっては，硫黄酸化物を含むガス の腐蝕に強いこと，熱疲労に耐えることの相反する 2 点について 検討したが，当初耐腐蝕性に重点をおき，肉厚鋳鋼を採用した。

ところが実操業の結果, クラック発生等の問題が生じたので検 討の結果鋳鋼の限界を知り，並行して試験を進めていた比較的薄 肉のボイラ鋼板の結果が良好であったので, 操業開始 2 年後これ に変更した。

（4）アップテークの泠却＼cjkstart本アップテークは炉の排ガス温度 を低下させるとともに, 水冷ジャケット表面温度を百数十度に維 持することによって付着溶融ダストがジャケット表面で急冷され， 収縮によってジャケット表面から娳離し易い状態になることを狙 ったものである。

一方, 表面温度が低下しすぎると硫酸化物による腐蝕が心配さ れた。

これらを解決するために, 冷却水は一部繰返して冷却水温度を コントロールできるようにした。

（5）ダストの除去 アップテークの機能を十分に発揮させる ため, 表面に付着する大量のダスト除去を目的にスートブロワ (ショート23本，ロング 2 本) を設置した。当初はその配置に問 題があり必ずしも満足すべき結果は得られなかったが，その後の 検討によりスートブロワを下部に重点的に配置するよう改善し て以来, ダスト除去は順調に自動的に行われるようになった。

\section{$3 \cdot 3$ セットラへの電極の設置}

水冷ジャケット式アップテークを採用すれば, 自熔炬のセット ラ部はアップテークからのバッククーリングと落下固体ダストに より冷却されることになる。この対策として排ガス量, 熱効率等 を考慮して電極による抵抗加熱を行うこととし, 併せて従来方式 の錬鍰炬部分を自熔炬内に取り込んで溶湯加熱と鍊鍰を行わせる こととした。
抵抗加熱を行う場合には，スラグ層の厚さを通常の自熔炉より 大きく保つので，スラグの滞留時間増による鍊鍰効果が得られ る。さらに電極周辺にはフラックスおよび固形物を装入可能な装 置を設けることとした。

電極の配置はその 2 本を極カアップテークに近づけるように配 慮した。

\section{$3 \cdot 4$ 自電炉法の得失}

自電炉の採用により, プラス面としては, 錬鍰炬とその排ガス 処理設備が不要のため,

(1) 建設費が少ない。

(2) 重油原単位が低く，操業人員が少なく，ランニングコスト が小さい。

また，電極をセットラへ設置しているため，

(3) 工程中間品処理が可能。

(4) 炬内の溶体温度コントロールがやり易い。 など有利な点が多い。

またマイナス面としては,

(1) アップテーク部の排水温度が $50 \sim 60{ }^{\circ} \mathrm{C}$ であるため, この廃 熱の回収が難しい。

(2) 電極が高温のガスに暴露されることによるペースト原単位 の増加, 電力原単位が鍊鍰炉より高くなる。

などがある。

\section{3・5 スタート時の操業状況}

操業開始以来，ボイラにおける大きなダストトラブルはなく， また, 炬操業面でも初期トラブルを除き，極めて順調に推移した。 自電炉の設備仕様を表 1 に, 操業当初の操業データを表 2 に示 す。

煙灰発生率は通常の自熔炉の $8 \sim 10 \%$ に対し，自電炉の場合は

表 1 自電炉設備仕様

\begin{tabular}{|c|c|c|}
\hline 名 称 & 基数 & 構 \\
\hline 乾蚂鉱ビン & 1 基 & 販鉱能力 $200 \mathrm{t}$ \\
\hline コンベヤ & 2 基 & $80 \mathrm{t} / \mathrm{h}$ \\
\hline 精鉱バーナ & 4本 & \\
\hline シャフト部 & 一式 & 内径 $6 \mathrm{~m} \phi \times 8 \mathrm{mH}$ 冷却制板 5 段 \\
\hline セットラ部 & 一式 & $\begin{array}{l}\text { 内径 } 19.75 \mathrm{~mL} \times 7 \mathrm{~mW} \\
\text { マットホール } 6 \text { 個 スラグホール } 2 \text { 個 } \\
\text { 重油バーナー: 正面 } 2 \text { 本、天井 } 6 \text { 本 }\end{array}$ \\
\hline 電気妒 & 一式 & $\begin{array}{l}\text { 電極 } 0.8 \mathrm{~m} \phi \times 3 \text { 本 自燒性電亟 } \\
\text { トランス容量 } 3,750 \mathrm{k} \text { V A }\end{array}$ \\
\hline アッフテーク & 一式 & $\begin{array}{l}\text { 内径 } 2.5 \mathrm{~m} \phi \times 9.4 \mathrm{mH} \\
\text { 水冷ジャケット }\end{array}$ \\
\hline 熱 風 妒 & & 蒸気加熱式 能力 $60,000 \mathrm{Nm} 3 / \mathrm{h} \times 450^{\circ} \mathrm{C}$ \\
\hline
\end{tabular}

表 2 操業当初の自電炉操業データ

\begin{tabular}{|c|c|c|}
\hline $\begin{array}{l}\text { 熔錬工場生産量 } \\
\text { 䙿銅 } \\
\text { 硫酸 }\end{array}$ & $\begin{array}{l}t / y \\
t / y\end{array}$ & $\begin{array}{l}101,000 \\
265,000\end{array}$ \\
\hline \multicolumn{3}{|l|}{ 装人 } \\
\hline 鉱石装人量 & $t / h$ & 43 \\
\hline 銅品位 & $\%$ & 25 \\
\hline 煙灰発生率 & $\%$ & $5 \sim 7$ \\
\hline \multicolumn{3}{|l|}{ 然料 } \\
\hline \multirow{3}{*}{ 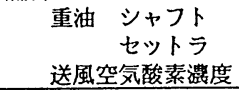 } & $\mathrm{L} / \mathrm{h}$ & $1,500 \sim 2,000$ \\
\hline & $\mathrm{L} / \mathrm{h}$ & $400 \sim 500$ \\
\hline & $\%$ & 21 \\
\hline \multicolumn{3}{|l|}{ 産出物 } \\
\hline マット量 & $t / d$ & 500 \\
\hline マット品位 & $\%$ & $50 \sim 52$ \\
\hline スラグ童 & $t / d$ & 450 \\
\hline スラグ中銅品位 & $\%$ & $0.52 \sim 0.65$ \\
\hline $\mathrm{Fe} / \mathrm{SiO} 0_{2}$ & - & 1.0 \\
\hline \multicolumn{3}{|l|}{ セットラ電極 } \\
\hline 電力使用量 & $\begin{array}{l}M W H / m \\
(\mathrm{~kW})\end{array}$ & $\begin{array}{l}1,500 \sim 1,700 \\
2,100 \sim 2,400\end{array}$ \\
\hline ベースト使用量 & $\mathrm{t} / \mathrm{m}$ & $25 \sim 30$ \\
\hline
\end{tabular}


5〜 7\%におさまっている。これはアップテークにおける付着ダ ストが高温のまま直接灯内に落下するため, ボイラ等で邻却され て繰返されるダストが少なくなったものと考えられる。

また, スラグホールはセットラ後面に 2 箇所あるが, アップテ ークより遠い箇所のものを常用している。スラグの $\mathrm{Fe} / \mathrm{SiO}_{2}$ は 1.0 程度に調節しており, スラグロスについては, 電気炉による 錬鍰も順調に行われ妥当な数值で推移した。また, 当時は重油専 焼であり, 酸素富化を行っておらず, マット品位は $50 \sim 52 \%$ とな っている。

\section{4. 自電炬操業改善の経緯}

玉野製鍊所は操業開始以来, 外的環境変化一対応して, 受託製 錬所としての競争力の強化のために, 種々の改善を実施してきた。 その中から,ここでは特に自電炉について改善の経緯を示す。

\section{昭和 47 年 1 月 操業開始 重油専焼 \\ 昭和 54 年 12 月重油, 粉コークス混焼操業実施}

昭和 56 年 4 月 第 1 期酸素富化 (マット品位 $58 \%$ )

微粉炭, 粉コークス, 重油混焼操業実施

昭和 57 年 4 月 アップテーク上部ボイラ化実施

昭和 58 年 12 月 $\mathrm{CO}$ 濃度コントロール開始

粉コークス, 重油混焼操業

昭和 59 年 4 月 第 2 期酸素富化 (マット品位 $60 \%$ )

電気炉電力削減開始

昭和 60 年 9 月 電気炉単相使用開始

昭和 61 年 4 月 アップテーク下部給水予熱実施

昭和 62 年 12 月 電気炉使用停止

この中から特に改善効果の大きいアップテークボイラ化と，燃 料転換, $\mathrm{C} O$ 濃度コントロールについて説明する。

\section{5. アップテークのボイラ化}

\section{$5 \cdot 1$ ボイラ化の検討}

水冷ジャケット式のアップテークの所期の目的であった排ガス の冷却によるボイラトラブル防止については，操業開始以来その 目的を達しており, 特に昭和 56 年の微粉炭混焼以後も順調な操業 を続け,その効果は顕著であった。一方, オイルショックを契機に して，銅熔鍊プロセスについても一連の省エネルギーが検討され， 対策が進められてきたが, その中で建設以来, 自電灯法でのマイ ナス部分である水冷ジャケット式アップテーク冷却水の熱回収の 検討を始めた ${ }^{2)}$ 。その後昭和 56 年に酸素プラントを設置して, 自 電炬に対して酸素富化操業を始めて以来, 排ガス量の減少に伴い 自電灯の蒸気発生量が減少し, 発電量が低下してきたため, この ジャケット冷却水の廃熱を蒸気として回収することができれば, 廃熱回収と発電設備のフル活用が同時にできる状況になった。

ボイラ化するに当たり，最も矁念したのは次の 2 点であった。

(1) 熱負荷が非常に高いための疲労による材料の強度低下（蒸 気波れの発生 )

(2) 水冷ジャケットからボイラチューブに变更した場合, 伝熱 面の表面温度の上昇 (百数十度より約 $350^{\circ} \mathrm{C} に$ ) により付着ダス トの剥離性が低下し，アップテーク内でダストトラブルが発生す る可能性がある。

この 2 点を確認するため, 昭和 54 年にはボイラメーカの協力を 得て, ジャケットの一部をボイラチューブに変更して 1 年間の耐 久テストを行った。

その結果, 材質の変化, ダストの付着状況について水冷式ジャ ケットとほとんど差が見られなかったため, 昭和 57 年に上部半分 をボイラ化した。ボイラ内圧力については, 低圧では腐蝕の問題
があること, また運転操作の複雑化を避けるため, 自電炉ボイラ の系統と同じ仕椂の蒸気圧力 $48 \mathrm{~kg} / \mathrm{cm}^{2}$ とし, 給水, 蒸気循環系 統もボイラと同一系統とした。

また，心配されるダストの剥離性に対しては次の対策を取った。

(1) ダストが剥離しやすいようにオメガチューブを使用し, 伝 熱面を平滑構造にした。

(2) 円筒形アップテークの 3 方向に水冷ジャケット面を残し, この部分にマンホール，スートブロワを設置した。

(3) ダスト除去のためにハンマリング装置を取り付けた。

また, この時ボイラチューブにしなかった下部については, 最 も熱負荷の高い場所であり, ダスト除去時の作業性の問題もあっ たので, ジャケットそのままとし，この部分の廃熱回収は今後の 課題とした。

\section{$5 \cdot 2$ ボイラ化後の操業}

昭和 57 年のアップテークのボイラ化後, 現在 8 年目の操業に入 っている。図了に自電炉ボイラの操業別の蒸発量の比較を示した が，従来の操業に比べ 1 時間当たり $3 \sim 3.5 \mathrm{t}$ の蒸発量が増加して いることがわかる。

腐蝕, 摩耗等によるチューブの損傷については, 定修時に肉厚 検査をしており，これまで特に問題は起こっていない。

内部へのダストの付着状況は, 上部のボイラ化部分はチューブ の表面温度,下部のジャケット部は冷却水の排水温度をモニタ して把握している。実操業では各部の温度変化をみながらスート ブロワの運転を行っている。アップテーク内部にダストが付着す ればこれらの温度は下がり, ダストが剥離すれば温度は上昇する。 両部共ダストの剝離が順調に行われていれば, 図4に示すように 周期的に温度変化が起こる。この状況を見ながらスートブロワの 運転パターンの採用, 変更を行っている。

その後, ジャケットのまま残された下部についての熱回収の検 討を進めたが，この部分については，投資利益率の関係から，ボ

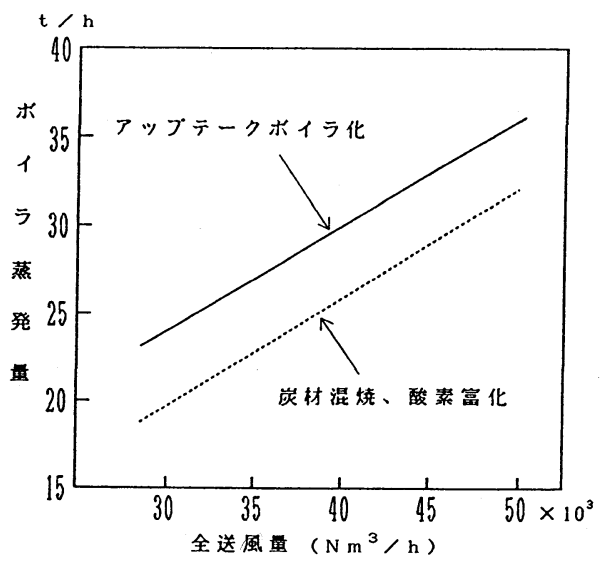

図 3 操業条件の変化による自電炬ボイラ蒸発量の変化

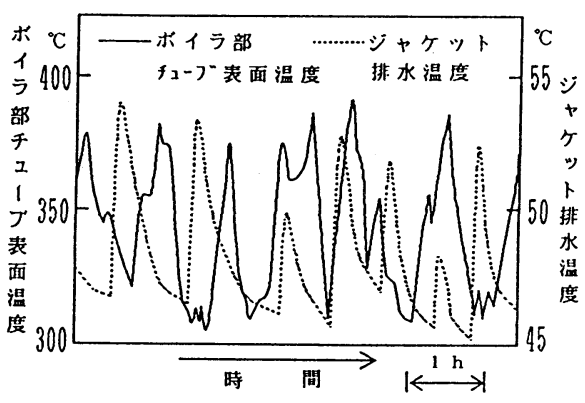

図4 アップテーク温度測定例 
表 3 ボイラ化の主な仕様

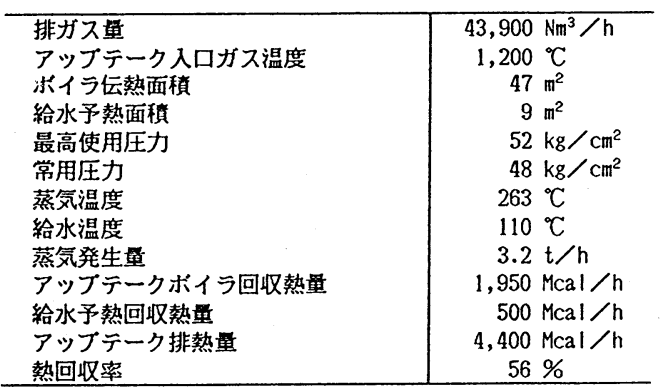

イラ化することを断念し，昭和61年よりボイラ循環水の給水予熱 に利用することとした。その結果, 熱回収伝熱面積は約 $9 \mathrm{~m}^{2}$ 増加 し, 回収熱量は約 $500 \mathrm{Mcal} / \mathrm{h}$ 増加した。現状のアップテークでの 廃熱回収の仕様を示すと表了のようになる。

\section{6. 燃料転換について}

\section{$6 \cdot 1$ 概要}

オイルショック以後, 図5に示すように, 重油価格が高騰した ため, 玉野製鍊所においても重油から安価な燃料への転換を始め $た^{3)}$ 。

図6に炭材への代替率の推移を示すが，まず昭和 54 年 12 月より 重油専焼から粉コークスの混焼に切替えた。燃料使用量も多い時 期であり, 酸素富化前でシャフトでの酸素濃度も低いため代替率 は30\%程度であったが, セットラの天井バーナを停止し, スラグ ロスやアップテーク内部へのダスト付着状況にも改善の徵候が見 られた。

昭和 56 年 4 月より, 第 1 期酸素富化でマット品位を $58 \%$ まで上 げる操業を開始した。このとき,コークスよりさらに安価な石炭 を粉砕して使用しはじめ, 重油, 粉コークス, 微粉炭の混焼操業 が昭和 58 年10月まで続いた。この間, シャフトの酸素濃度を $28 \%$ まで上げたため, シャフト内での炭材の燃焼率も向上し, 代替率 は80\%を超えるようになった

炭材の使用量が増えるに従い, 炉況が以前と異なる様相を呈し てきたため, 师内の状況を把握する必要性が増してきた。解析す べき因子を検討したが，炉況に影響を及ぼしている主な要因は， セットラ上の未燃炭素であるという推定をして，CＯ濃度を測定 することとし, 昭和 56 年 10 月にシャフト出口にC O 濃度計を設置 し，炬内雲囲気の測定をはじめた。

昭和 58 年 10 月以降は, 微粉炭から粉コークスヘ変更し石炭粉砕 を停止した。微粉炭をやめ, 炭材を全量コークスとした頃から,
炬内における還元効果が顕著になった。

この頃までに, すでにセットラ内の C O 濃度の動きを把握して おり，還元効果をコントロールすれば炉況を健全に保てることを 確認していたので, 昭和 58 年 12 月より C O濃度コントロールを開 始した。その結果，スラグロスは更に低減でき，セットラ内に設 置している電気炉の電力も減少させることができた。

\section{$6 \cdot 2$ 混焼操業結果}

表 4 に混焼前後の操業データを示す。

$52 \%$ のット品位では炭材使用により, シャフト出口のガス温 度がわずかに下がり，また，マット温度も低目で操業が可能とな っている。加えて, マグネタイトが $6.5 \%$ から $4.8 \%$ へ低下したこ とおよび，酸素分圧が 1 桁低下したことにより還元が強まってい ることがわかる。

この理由は, シャフト内で未反応の炭材がセットラスラグ上に 残り，スラグを効果的に還元しながら加熱したためである。

酸素富化した後, マット品位が $60 \%$ になってからは, マット温 度を高くキープするためガス温度も上がっているが, 混焼以前よ りはやや低い温度でおさまっている。

酸素分圧, マグネタイトの挙動についても未燃炭素の還元効果 がよく表れている。

炭素による還元効果の最も顕著な例としてスラグロスへの 影響があるが，これは C O 濃度コントロールの項で述べることと する。

アップテークにおけるダストの付着状況の変化を示すために, 図 7 に冷却水の入出口温度差（以下 $\Delta T$ と呼ぶ）の変化を表した。 ダストの付着が少なければ出口温度は高くなるので $\Delta T$ は大き くなり，良好な操業状態と言える。

この図より，混焼前に比べ混焼後は $\Delta T$ がはっきりと上がって 表 4 炭材混焼前後の自電炉操業データ

\begin{tabular}{|c|c|c|c|c|}
\hline & & 混焼前 & & \\
\hline マット品位 & $\%$ & 52 & 52 & 60 \\
\hline 温度 & ${ }^{\circ} \mathrm{C}$ & & & \\
\hline シャフト出ロガス & & 1,270 & 1,220 & 1,250 \\
\hline マット & & 1,190 & 1,164 & 1,180 \\
\hline スラグ & & 1,254 & 1,253 & 1,260 \\
\hline アッブテーク入ロガス & & - & 1,190 & 1,200 \\
\hline スラグ中 $\mathrm{F} e_{3} \mathrm{O}_{4}$ 品位 & $\%$ & 6.5 & 4.8 & 5.4 \\
\hline $\mathrm{P}_{02}$ (セットラ） & atm & $2 \times 10^{-9}$ & $4 \times 10^{-18}$ & $2 \times 10^{-10}$ \\
\hline $\mathrm{P}_{02}$ (アッブテーク) & atm & - & $10^{-18}$ & $10^{-18}$ \\
\hline 電気炉投人電力 & KWH & 2,270 & 2,140 & 2,150 \\
\hline ペースト使用量 & $\mathrm{kg} / \mathrm{d}$ & 900 & 840 & 870 \\
\hline
\end{tabular}

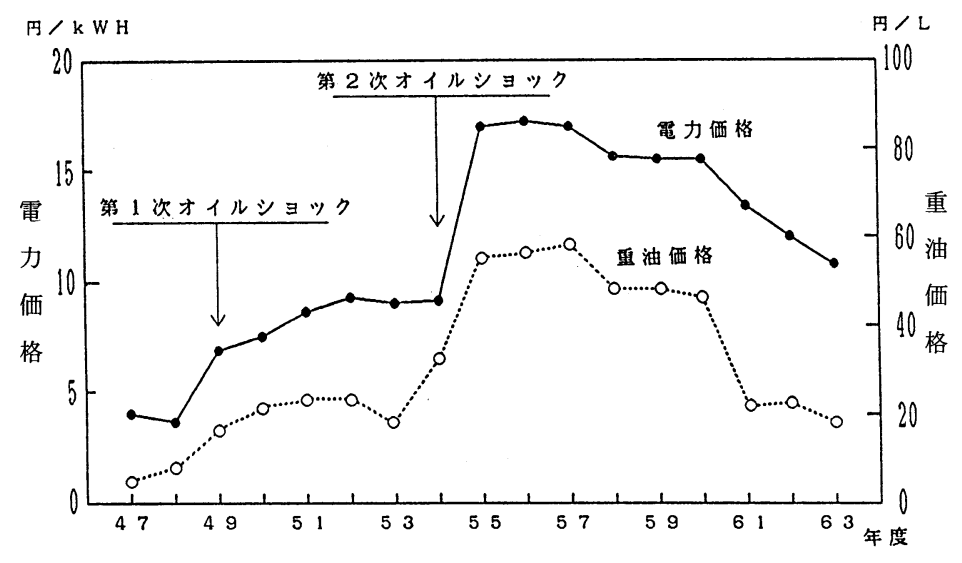

図 5 電力価格, 重油価格の推移

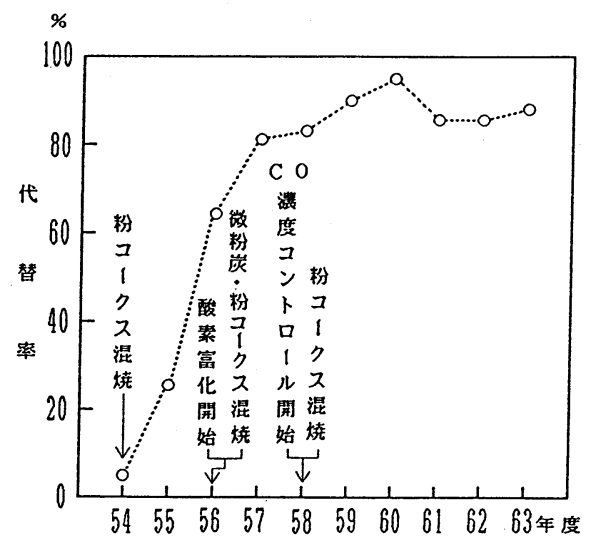

図6炭材への代替率の推移 

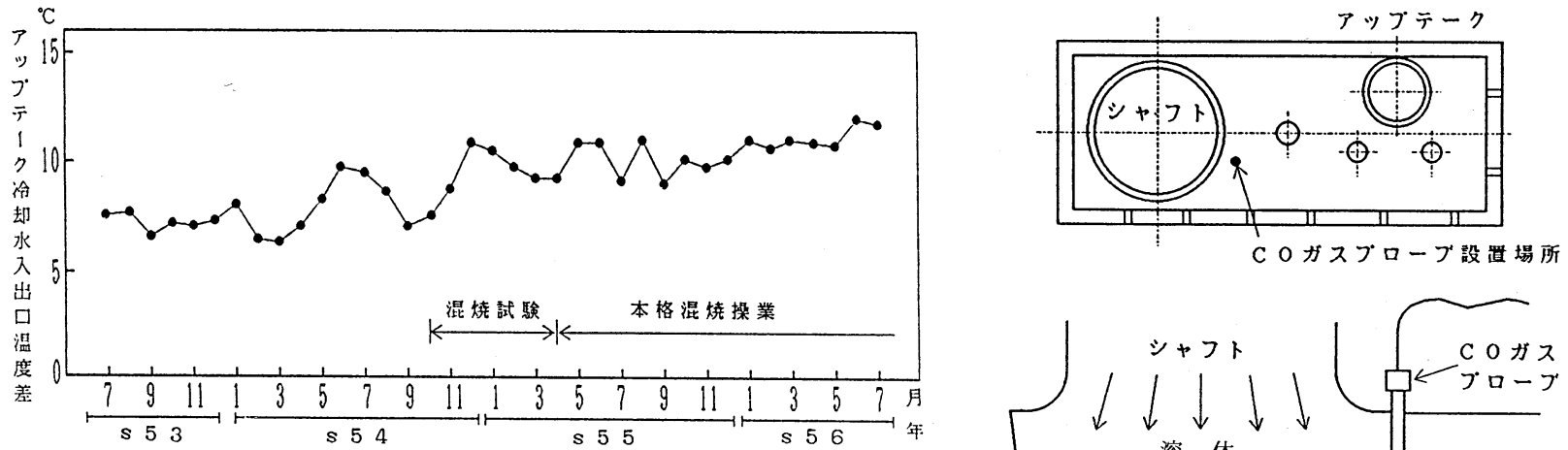

図7炭材混焼前後のアップテーク冷却水入出口温度差の推移

いるのがわかる。これは混焼後はセットラ内スラグ表面での燃焼 熱でアップテーク最下部のダストを溶かすため, ダストの成長が 防止でき，また，炉内の還元雾囲気でダストの性状が軟質化し除 去しやすくなって，スートブロワによりダスト除去が順調に行わ れていることを示している。

その他, 不純物の分配にも変化が表れた。図 8 に $\mathrm{Pb}, \mathrm{Zn}, \mathrm{As}$, $\mathrm{Sb}$ のマット，スラグへの分配を示したが，いずれも混焼後はマ ット中への歩留が増えており，混焼における数少ない欠点と言え る。

\section{6・3 C O 濃度コントロールと電気炉電力の削減}

微粉炭，粉コークスの使用を開始して以後，約 2 年間にわたっ て自電炉セットラ内の C O 濃度の測定を行いながら, 炉内温度状 況，スラグ組成および物質収支等を調査した。

これらの結果より, 炉内 C O 濃度をコントロールすれば排出ス ラグ中の銅品位を低下させること，セットラ内の温度保持にも有 効であることが判明したため, それ以後は C O 濃度を自電炉操業 の重要なコントロールポイントの1つとして取上げて操業を行う こととした ${ }^{5)}$ 。

（1）ＣＯ濃度測定結果とコントロール方法 C O 濃度計は赤 外線式とし，ガスはシャフト排ガスを代表する場所としてシャフ
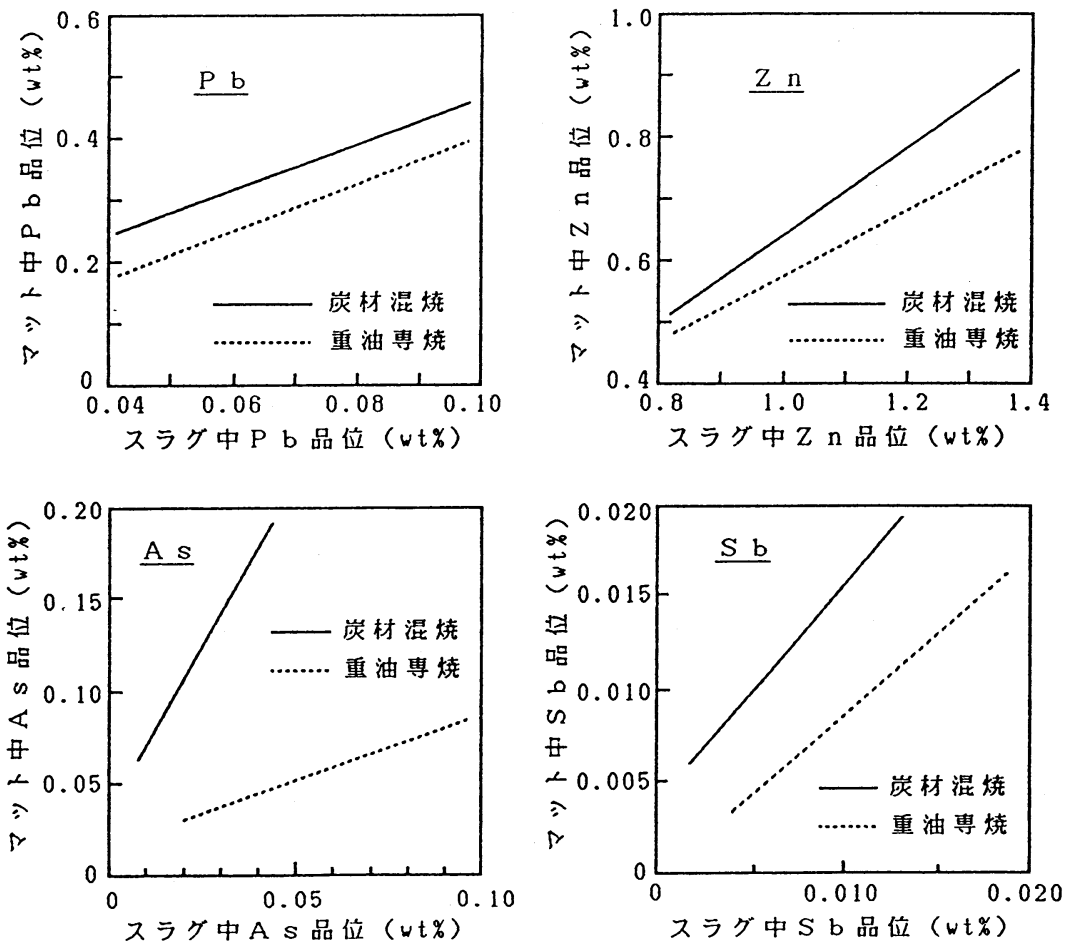

図8 マット；スラグ中微量元素の分配
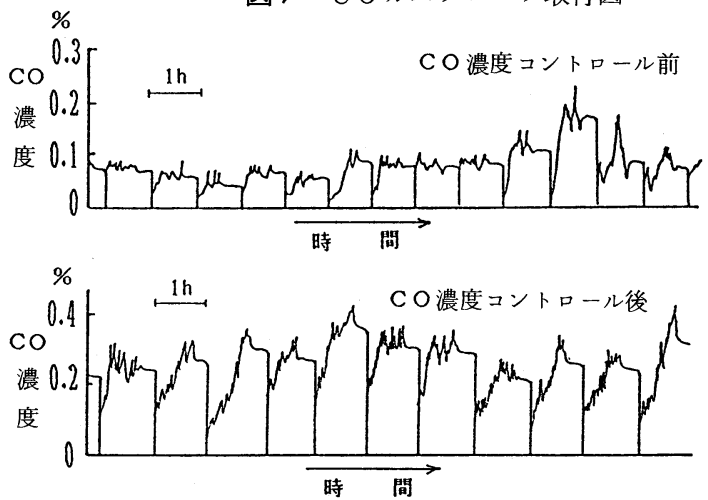

図10 自電炉炉内 C O 濃度測定例

ト出口のセットラ湯面上約 $30 \mathrm{~cm}$ のところら吸引し, フィルタ を通し冷却後 $\mathrm{C} O$ 濃度計におくる。

吸引管内のダスト除去のために, 定期的にガス吸引を停止しェ アーパージする方法をとった。図9にその設 置場所を示す。

シャフト排ガスが, 平衡値に達していると 仮定して, 当所の操業条件で排ガス中の C O 濃度を計算してみると, $0.5 \sim 0.8 \%$ 程度とな る。実際に測定してみると, 通常 $0 \sim 0.1 \%$ 程

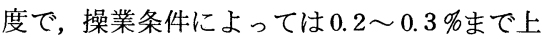
昇することが見られた。

自電炉においては, マット温度およびマッ ト品位をコントロールするために送風量, 補 助然料を調整しているが，通常のバランス点 から粉コークス量をわずかに多くしてやると $\mathrm{CO}$ 濃度が上昇し，そのコントロールも可能 である。0.2〜0.3\%程度にコントロールした 例を図10に示す。C O濃度コントロールとは, C O 濃度をモニタし, それをフィードバック させて炭材量を調整することにより最終的に マット温度, マット品位, $\mathrm{C} O$ 濃度の 3 因子 を同時にコントロールするものである。

(2) C O濃度コントロールの効果のくスラ グ中銅品位の低下 $>\quad \mathrm{CO}$ 濃度コントロー ルのスラグ中銅品位に及ぼす効果をスラグ組 成 $\mathrm{Fe} / \mathrm{SiO}_{2}$ およびマット品位に対して示し たのが図11である。C O 濃度コントロールに 

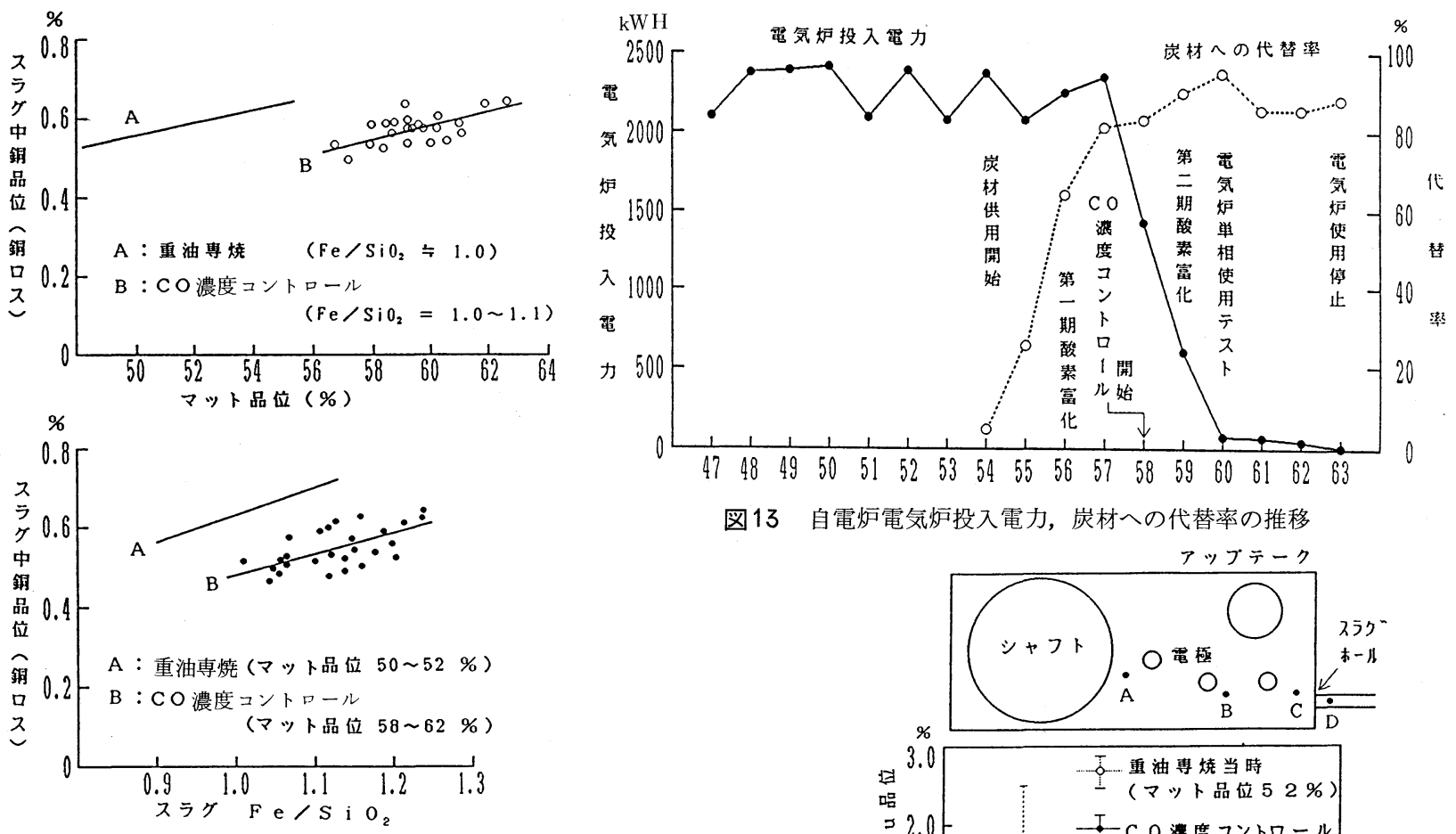

図13 自電炉電気炬投入電力, 炭材への代替率の推移
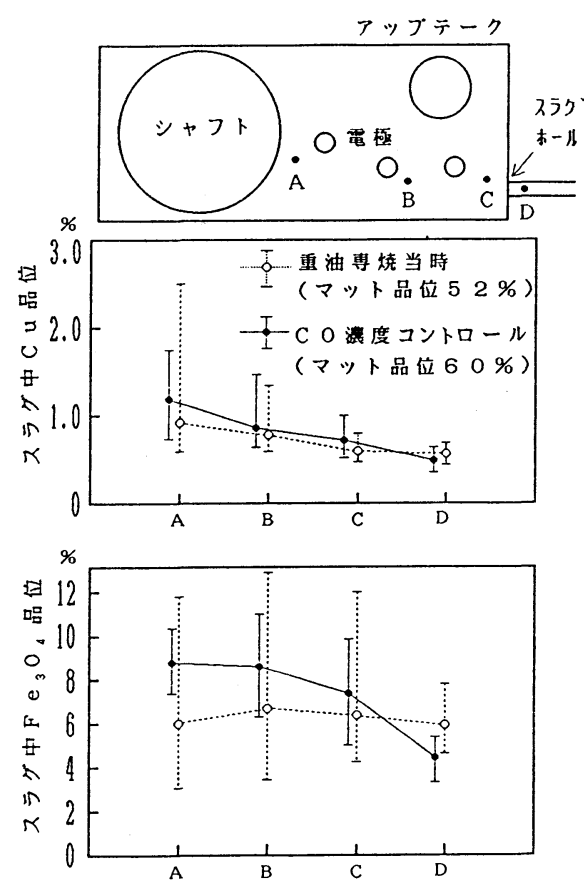

図11 銅ロスに対するCO濃度コントロールの効果

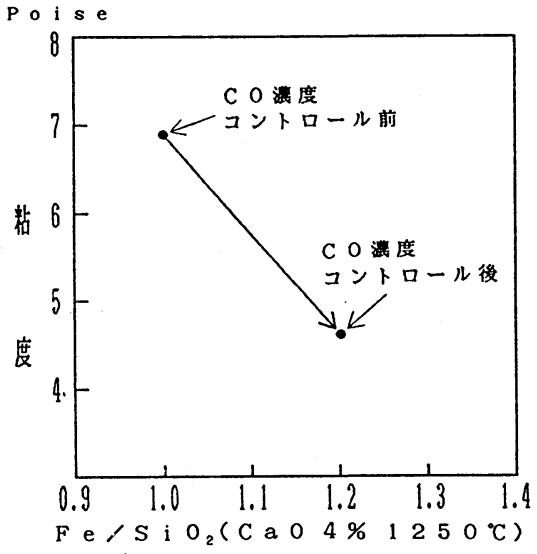

図12 スラグの粘度と $\mathrm{Fe} / \mathrm{SiO}_{2}$ の関係

より，スラグ中銅品位が低下していることがはっきりわかる。

これらの結果より, 実操業においては従来スラグ中の $\mathrm{Fe} / \mathrm{SiO}_{2}$ を $1.0 \sim 1.1$ 程度でコントロールしていたものを 1.2 以上にあげて スラグ量を減少させて操業を行っているが，スラグ中の銅品位は $0.6 \%$ 前後でおさまっている。

実際のスラグの粘性を調查した結果を図12に示す。この図は, $\mathrm{C} O$ 濃度コントロールによるスラグ組成の変更と, マグネタイト の減少によりスラグ粘性が低下したことを示したものであるが, これもスラグ中銅品位低下の一因となっていると考光られる。

その他の効果としては，セットラ内のスラグ温度の水平分布も 調査したが，セットラ全体にわたって，かなり温度が均一化され ている傾向が見られた。

（3）ＣＯ濃度コントロールの効果 (2)〈電気炉電力の削減〉 自電炬における燃料の代替率と電気炉電力の推移を図13に示す。 混焼を開始してから, シャフト部における重油と炭材の代替と 並行して, セットラ部での保温用重油が減少し, 昭和56年には自 電炉での全セットラバーナを停此できた。電気炉電力については, 昭和58年にCO 濃度コントロールを開始してから急激に電力を減 少させることができた。 
表 5 スラグロスの形態分布推定

\begin{tabular}{|c|c|c|c|}
\hline & \multicolumn{2}{|c|}{ 重油専燒 } & C O 濳度 \\
\hline マット品位（\%） & 50 & 60 & 60 \\
\hline 酸化態 C u (\%) & 0.19 & 0.28 & 0.19 \\
\hline 硫化態 C u (\%) & 0.25 & 0.20 & 0.20 \\
\hline 棌 垂 $\mathrm{C} u$ (\%) & 0.14 & 0.18 & 0.14 \\
\hline 合 計 $\mathrm{Cu}(\%)$ & 0.58 & 0.66 & 0.53 \\
\hline
\end{tabular}

電気炉停止後については, 銅はマット品位が高いためもあるの か, $\mathrm{A} \sim \mathrm{B}$ 点は平均的に高くなっているが， $\mathrm{D}$ 点の排出スラグは 健全な数値まで下がっていることがわかる。

マグネタイトの数值には還元効果が如実に表れている。A点で は，はるかに高かったものが， B， C，D点と行くにつれて減少 している。さらにバラッキについては，CO濃度コントロール後 の方が小さく，シャフト内での反応そのものが以前より，より均 一な雾囲気で行われていると言える。

このことから電気炉では, 懸垂マットのセットリングには有効 であるが，炉内雾囲気調整はできないため，マグネタイトのコン トロールにはそれ程効果はない。しかし, 炭材使用による C O 濃 度コントロールでは, スラグ流動性の向上によるセットリングと ともに雾囲気調整を行えるため, 電気炉以上の機能をもっていると 言い得る。

最後にスラグロスを熱力学, 実験式, 操業データ等から計算し, 推定してみた。

計算結果および操業実績の銅品位を用いてＣＯ濃度コントロー ル下における酸化態の銅品位を推定すると，表 5 のようになる ${ }^{7)}$ 。 この表にみられるように, 酸化態の銅の減少が全体のスラグロス に大きく奇与していることが推定される。

以上より， C O 濃度コントロールのスラグロスへの効果を要約 すると, 次のようになる。

(1) スラグ中銅品位の低下は，電極による錬鍰より大きい。

(2) スラグ中のマグネタイトが減少したため, スラグ組成，す なわち $\mathrm{Fe} / \mathrm{SiO}_{2}$ を1.0より 1.2 程度に上げ，スラグ量を減少する ことができる。

(3) スラグの鍊鍰作用を行わせるのに必要なエネルギーコスト が大幅に削減できる。

\section{$6 \cdot 4$ 現在の自電炉操業状況}

表 6 操業当初と現在の自電炬操業データ

\begin{tabular}{|c|c|c|c|}
\hline & & 操業当初 & 現 在 \\
\hline \multicolumn{4}{|l|}{ 塎鍊工場生产量 } \\
\hline 辒銅 & $t / y$ & 101,000 & 196,000 \\
\hline 硫酸 & $t / y$ & 265,000 & 450,000 \\
\hline \multicolumn{4}{|l|}{ 装人 } \\
\hline 鈗石装入量 & $t / h$ & 43 & 72 \\
\hline 銅品位 & $\%$ & 25 & 28 \\
\hline 煙灰発生率 & $\%$ & $5 \sim 7$ & $5 \sim 7$ \\
\hline \multicolumn{4}{|l|}{ 燃料 } \\
\hline 重油 シャフト & $\mathrm{L} / \mathrm{h}$ & $1,500 \sim 2,000$ & $60 \sim 100$ \\
\hline セットラ & $\mathrm{L} / \mathrm{h}$ & $400 \sim 500$ & 0 \\
\hline 炭材 & $\mathrm{kg} / \mathrm{h}$ & 0 & $2,000 \sim 3,000$ \\
\hline 送風空気酸素濃度 & $\%$ & 21 & $28 \sim 30$ \\
\hline \multicolumn{4}{|l|}{ 産出物 } \\
\hline マット量 & $t / d$ & 500 & 700 \\
\hline マット品位 & $\%$ & $50 \sim 52$ & 60 \\
\hline $\begin{array}{l}\text { スラグ量 } \\
\text { スラグ銅品位 }\end{array}$ & $t / d$ & $\begin{array}{r}450 \\
0.52 \sim 0.65\end{array}$ & $\begin{array}{r}800 \\
0.50 \sim 0.65\end{array}$ \\
\hline $\mathrm{Fe} / \mathrm{SiO} 0_{2}$ & - & $\begin{array}{r}0.0200 \\
1.0\end{array}$ & $\begin{array}{r}0.000 \\
1.2\end{array}$ \\
\hline \multicolumn{4}{|l|}{ セットラ電拯 } \\
\hline \multirow[t]{2}{*}{ 電力使用量 } & $M W H / m$ & $1,500 \sim 1,700$ & 0 \\
\hline & $(\mathrm{kW})$ & $2,100 \sim 2,400$ & 0 \\
\hline ベースト使用量 & $t / m$ & $25 \sim 30$ & 0 \\
\hline
\end{tabular}

表 6に操業開始当初と現在の自電炉操業データの比較を示す。 粗銅生産量は約 2 倍となり, 当初シャフト, セットラへ多量に 使用していた重油はシャフトにわずかに残るのみで，ほとんどが 炭材に置きかえられた。

二度の酸素富化の後, マット品位も50 52\%から60\%に上昇し たが，スラグロスは以前のマット品位の低い時期と同レベルであ り, 逆に $\mathrm{Fe} / \mathrm{SiO}_{2}$ は 1.0 から 1.2 に上げて操業している。

電気炬においては, 炭材使用後の C O 濃度コントロール以後, 段階的に電力を削減し，遂に完全停止した。

また, 還元と炉内の均一加熱の効果により, 炉底のビルドアッ プが防止でき，アップテークへのダスト付着成長が防止され，炬 内点検時間が減少するなど，ただ単に電気炉を停止しただけでな く操業の安定に大きく寄与している。

\section{7. 改善の成果}

自電炉プロセスは廃熱ボイラトラブルの回避を主目的として, 従来の自熔炉法を改良したものであるが，次の 2 点が弱点として 残っていた。

(1) アップテークがジャケット横造のため低温冷却水の廃熱回 収ができない。

(2) 電極をセットラに内蔵したため, ペースト消費量, 電力消 費量が鍊鍰炉より高くなる。

これまで述べた改善は上記 2 点を解消したもので, 自電炉法の 所期の目的であるボイラトラブルを回避しつつさらに改善できた ことからも，本来の自電灯法の有利性が確認できたと言える。

個々にはアップテークボイラ化で, ボイラ入口温度を上げるこ となく年間約 $5,000 \mathrm{MWH}$ の発電量をアップさせ, 最近はジャケッ 卜部でボイラ用給水を予熱しており,さらに省エネ効果を増幅さ せている。

燃料転換は燃料コストの削減はもちろん, 電気炬コスト,すな わち電力, ペースト, ケーシング, さらにメンテナンスに要する 工数等の削減を行うことができた。

図15に自電炉における総燃料コストの推移を示す。昭和53年を $100 \%$ とすると, 第 2 次オイルショック後は $220 \%$ まで急上昇し た。この後改善の効果が徐々に現れ, 昭和 63 年には昭和 53 年 の $50 \%$ ，昭和 55 年と比較すると実に $25 \%$ まで減少している。この 中には土ネルギー単価自身の值下がりも含まれてはいるが, 高価 な電力, 重油から安価な炭材へのシフトがスムーズに行われたこ とがわかる。また炭材についても，使用量は少しずつ増加してい るものの, 安価な銘柄に切換えているため, 総コストを増加させ

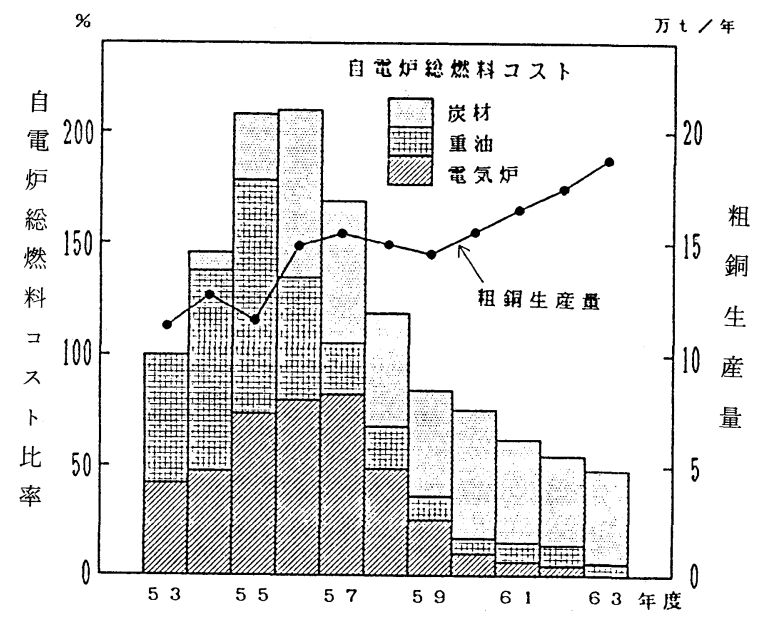

図15 自電炬総燃料コストと粗銅生産量の推移 


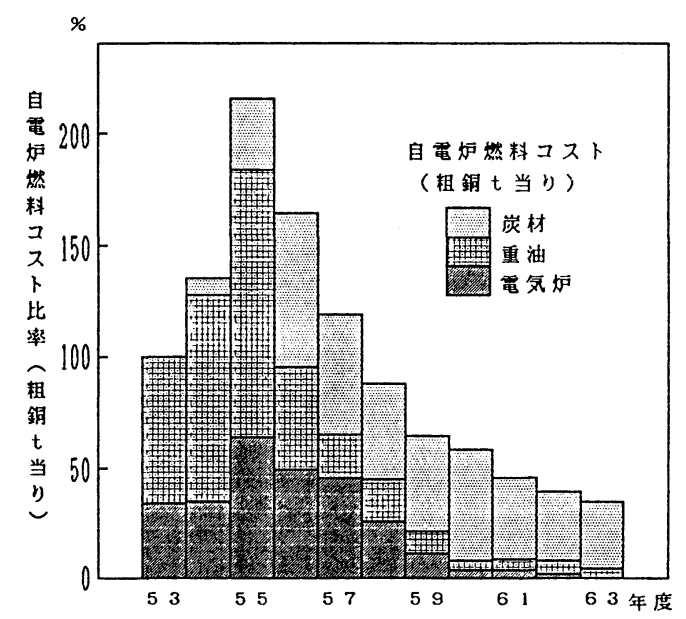

図16 粗銅 $\mathrm{t}$ 当たりの自電炉燃料コスト推移

ずにすんでいる。この間の粗銅生産量が約 2 倍になっていること から粗銅単位原価は図16に示したように, 大幅に減少している。

上述した効果は日本国内におけるェネルギー価格体系に適応し た操業方法の改善であるが，別の見方をすれば，自電炉法はエネ ルギー価格条件に柔軟に対応できるプロセスになり得たとも言い 得る。

すなわち, 相対的に電力エネルギーの安価な地域ではオリジナ ルの自電炉法を主体とした操業方法が, また日本と似たような条 件の地域であれば改善した操業方法がフルに適用できることにな る。

\section{8. 結言}

高度成長時代末期に操業を開始し, 順調な立ち上がりで推移し
てきた当所は，第 1 次オイルショックにより大きな打撃を受けた。 その後, 銅市況および銅価低迷の中で第 2 次オイルショックや円 高の影響を受け，製錬所として非常に厳しい状況にさらされたが， すばやく省エネルギー・燃料転換に取組み, 幾多の問題を解決す ることにより，「アップテークのボイラ化」・「重油, 電力より 炭材へのエネルギー転換」の技術を確立した。

自熔炉プロセスは，かなりの歴史を有するが，これらの改善に よ一て今日の時代に適応した銅製鍊プロセスの 1 つに育てること ができてきたものと考えている。

最後に、これら技術改善の基礎を築いていただいた三井金属鉱 業および古河機械金属の諸先輩，筆者の前任者ならびに,この技術 確立に当たり絶大なるご努力とご協力を賜った関係各位にこの 紙面を借りて深く感謝の意を表す次第である。

\section{参考文 献}

1) 北村：日本鉱業会誌, 91[1049]，465, (1975)

2）丸山・上川：非鉄製錬技術と省エネルギー，246-252，(1985）， 日本鉱業会

3) S. Okada, M. Miyake, A. Hara and M. Uekawa: Sulfide Smelting Symposium, San Francisco, USA, $855-874,(1983)$

4) S. Okada, M. Hashiuchi and M. Uekawa: The 4 th International Flash Smelting Congress, USA, Mexico, 299-314, (1981)

5）柴田・丸山・上川・老田：非鉄製鍊技術と省エネルギー，151-158 (1985), 日本鉱業会

6) T. Watanabe, S. Okada and S. Muto: Australia Japan Extractive Metallurgy Symposium, Sydney, Australia, 31-39, (1980)

7) T. Shibata, Y. Oda and T. Maruyama: The 5 th International Flash Smelting Congress, Finland, Poland, 249-262, (1986)

\section{新刊紹介}

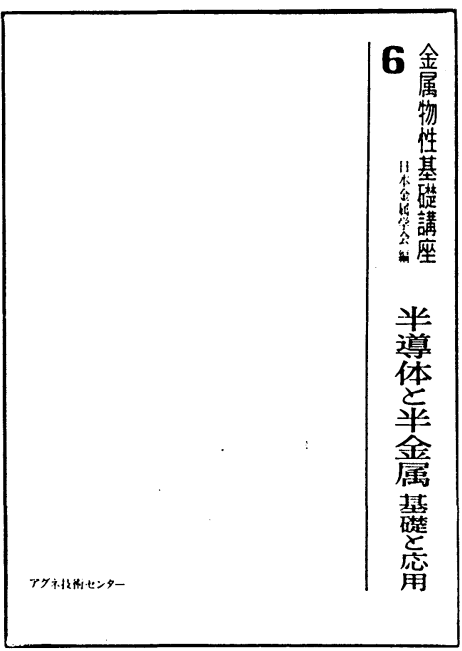

\section{日本金属学会編金属物性基礎講座}

“半導体と半金属 基礎と応用”

\section{アグネ技術センター $1990<\mathrm{A} 5 \cdot 532$ 頁・8,240円 $>$}

本書は, 近年めざましいまでの展開を示 しつつある半導体と半金属を対象とし, 主 として物性物理学, 材料科学の立場から解 明と展望を与えたものである。

産業の米といわれるまでに発展した半導 体, その技術向上は止まるところを知らな いようで，数年前の新鋭技術がすでに現在 では色あせて見えさえするのである。

現在のわが国の高度技術は, 国外からの 基礎技術導入によって築き上げられたもの が多く,これを巧みに消化し，改良して， 今や世界の第一線にあるのだが，先頭を走 り続けるためには, 自らの創造による基本 的な独自の新技術の開拓が必要とされる。

基礎のないところから, 新しい展開の芽 は生まれない。本書は基本に立ち帰っての
学習に役立つことを目的として編まれたも ので, 基礎の理解から応用への展開につな がることを期待している。（序より拔粋）

$$
\text { 目次 }
$$

1 電子と正孔

2 キャリヤーの輸送

3 光学的性質

4 発光とエクシトン

5 接合

6 界面現象

7 ビスマスー半金属の典型として

8 化合物半導体

9 半導体の照射効果

10 強磁場下に拉けるインジウム・アン チモナイド

(株) アグネ技術センター：03(409) 5329 